\title{
Heavy metals risk assessment in water and bottom sediments of ICOLLs in northern Poland
}

\author{
Astel A. ${ }^{1,}{ }^{*}$, Bigus K. ${ }^{1}$, Obolewski K. ${ }^{2}$, Niedzielski P. ${ }^{3}$, Stec M. ${ }^{1}$, Astel K. ${ }^{1}$ and Tsakovski S. ${ }^{4}$ \\ ${ }^{1}$ Institute of Biology and Environmental Protection, Faculty of Mathematics and Natural Sciences, Pomeranian University in Słupsk, 22b \\ Arciszewskiego Str., 76-200 Słupsk, Poland \\ 2Department of Hydrobiology, University of Kazimierz Wielki in Bydgoszcz, 30 Chodkiewicza Str., 85-064 Bydgoszcz, Poland \\ ${ }^{3}$ Department of Analytical Chemistry, Faculty of Chemistry, Adam Mickiewicz University, Umultowska 89, 61-614 Poznań, Poland \\ ${ }^{4}$ Department of Analytical Chemistry, Faculty of Chemistry, University of Sofia "St. Kl. Okhridski", 1164 Sofia, J. Bourchier Blvd. 1, \\ Bulgaria \\ Received: 21/02/2018, Accepted: 13/07/2018, Available online: 26/09/2018 \\ *to whom all correspondence should be addressed: e-mail: aleksander.astel@apsl.edu.pl, AliAst@poczta.fm \\ https://doi.org/10.30955/gnj.002634
}

\begin{abstract}
Natural diversity of intermittently closed and open lakes and lagoons (ICOLLs) depends on mutual interactions of several factors: (i) an impact of sea water and land background; (ii) temporary meteorological situation; (iii) hydrological conditions; and (iv) the shape of lake basin. However, some regional, local or even sudden impacts including anthropogenic ones create their final ecological status. To identify heavy metals risk assessment in ICOLLs located in Polish coastline wide range of them were determined in water and bottom sediment samples collected in 10 water reservoirs. Multidimensional data set of 20 variables was explored by the use of chemometrics according to seasonality (Spring, Summer, Autumn), sample type (water, sediment) and level of isolation (fully isolated, partially and fully connected lakes). The results showed that $70.5 \%$ and $77 \%$ of the data variance can be explained by the use of principal component analysis for waters and sediments, respectively. Waters of fully isolated or partially connected lakes are more abundant with Ir, Nd and Sm, while less abundant with $\mathrm{Pr}$ and Sr. Bottom sediments taken from Jamno lake show significant contamination by heavy metals of the highest environmental concern (Al, $\mathrm{Cr}, \mathrm{Cu}, \mathrm{Ni}, \mathrm{Ti}$ and $\mathrm{Zn}$ ).
\end{abstract}

Keywords: Baltic Sea, coastal lakes and lagoons, heavy metals, multivariate analysis, spatiotemporal variation.

\section{Introduction}

Intermittently closed and open lakes and lagoons (ICOLLs) are brackish coastal water reservoirs with a connection to the sea that is periodical due to seasonal, littoral accumulation of marine sediment forming an entrance berm (Haines, 2006) or artificially built bars. ICOLLs are found in wave-dominated coasts (McSweeney et al., 2017), however globally their presence is not very common (Haines et al., 2006). It is estimated that they appear along $8-13 \%$ of the worldwide coastline (McSweeney et al., 2017). The hydrological dynamic of ICOLLs, in particular the equilibrium between water and bottom sediments, are related to wave energy, sea-water intrusions and river discharge. Periods of low river discharge facilitate deposition of sediments and particulate matter immobilization in deep water while periods of high wave energy facilitate sea water intrusions and resuspention of bottom sediments. Therefore, metals present in aquatic ecosystem of coastal lakes might be released or immobilized according to seasonal variation of ICOLLs hydrology and domination of river and sea impact, respectively.

Heavy metals abundance in aquatic ecosystems have received worldwide attention due to their toxicity, immobilization/discharge according to $\mathrm{pH}$ value as well ability to accumulation in biota. Metals enter the aquatic environment in dissolved and particulate phase through natural processes (atmospheric deposition, soil erosion) and anthropogenic sources (industrial, agriculture runoff, domestic). Relatively high solubility of metals results in their uptake, and hence bioaccumulation, by aquatic plants and organisms and finally biomagnification along the food chain. Some of metals, such as cadmium or lead are toxic to living organism at trace concentrations and this is why the group of metals of the highest environmental concern include: $\mathrm{As}, \mathrm{Cd}, \mathrm{Cr}, \mathrm{Cu}, \mathrm{Ni}, \mathrm{Ag}, \mathrm{V}$, $\mathrm{Zn}, \mathrm{Pb}$ and $\mathrm{Hg}$, however other metals are also important. Heavy metals in particulate phase can be deposited as bottom sediments which could be also considered as a secondary source of metals due to remobilization resulting in their gradual release to the water reservoir or to aquatic organisms.

Range of studies have been conducted on the most emerging heavy metals distribution both in brackish aquatic systems including their water (Bahnasawy et al., 2011), bottom sediments (El-Amier et al., 2017; Elkady et al., 2015; Fujita et al., 2014; Honglei et al., 2008; Huang et al., 2013) or biota (Bahnasawy et al., 2011; 
Elkady et al., 2015) and freshwater ones (Carral et al., 1995; Guo et al., 2015; Jiang et al., 2012). However, only few studies concern individual coastal lake of Polish coast (Daniszewski and Konieczny, 2013; Cieśliński, 2003; 2009) while none of them concern majority of ICOLLS present on Polish coast and such huge range of metals as reported in this study. Therefore, in this study, 10 ICOLLs different according to their connectivity towards Baltic Sea were selected to seasonal exploration of 20 metals' concentration in water and bottom sediment by the use of principal component analysis.

\section{Materials and methods}

\subsection{Sampling and analysis}

The present study was performed at 10 coastal lakes and lagoons: Ptasi Raj, Łebsko, Jamno, Gardno, Dołgie, Kopań, Wicko, Sarbsko, Resko and Liwia Łuża along the distance of $775 \mathrm{~km}$ of Polish coast (Figure 1).

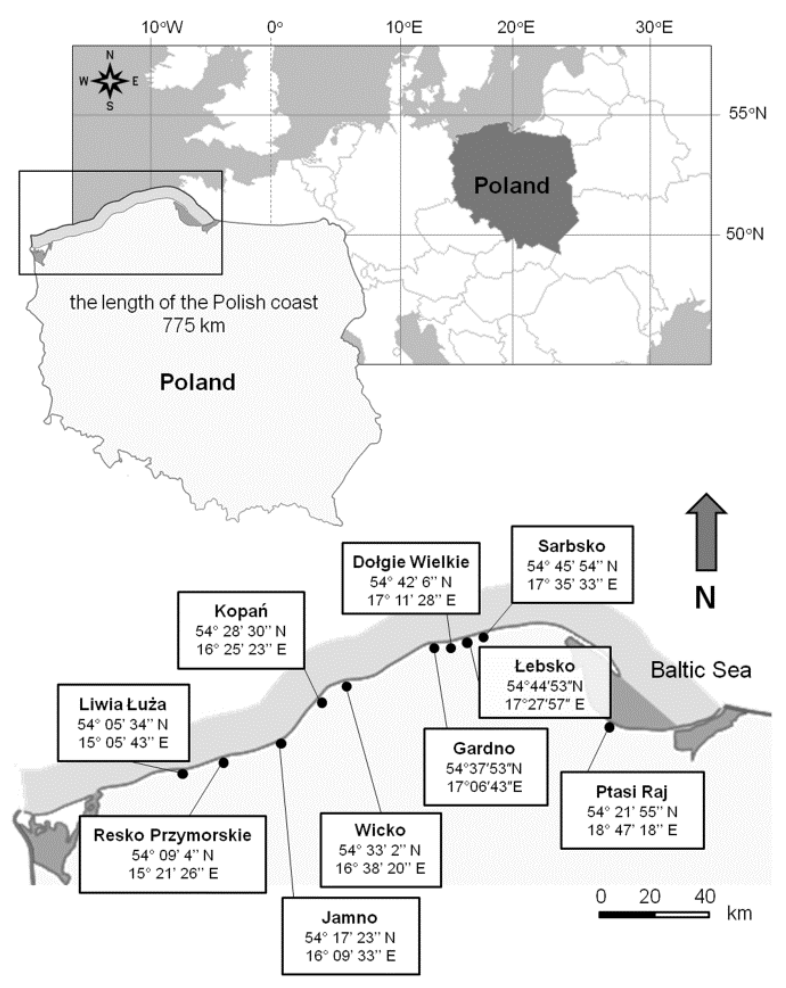

Figure 1. Location of ICOLLs along the distance of Polish coast

A total of 170 bottom sediment (up to $20 \mathrm{~cm}$ depth) samples were collected using an Eckman grab sampler according to Ivanter et al. (2016). Moreover, a total of 180 water samples were collected from the boat to polyethylene containers of $1.5 \mathrm{dm}^{3}$ volume. In each lake 4 to 11 samples (both water and sediments) were taken in locations established according to the longest vertical and horizontal transects conducted across the lake. Detailed hydrochemical properties of lakes including the name of the feeding stream, hydrological connectivity as well as Venice and hydrographic classifications are presented elsewhere (Obolewski et al., 2015). The information significant for this study is that ICOLLs represent three levels of isolation, i.e.: fully isolated (I), partially (PC) and fully connected (FC) with the Baltic Sea while sampling campaigns were organized 3 times a year, starting in April, 2014 and finishing in November, 2014 to cover Spring, Summer and Autumn seasons. Sediment samples were placed to disposable polyethylene containers of $0.1 \mathrm{dm}^{3}$ volume and transported to the laboratory in temperature lower than $8^{\circ} \mathrm{C}$. In the lab they were dried in temperature of $65^{\circ} \mathrm{C}$ and ground into a fine homogenized powder. For the metal analyses, $1 \mathrm{~g}$ of the sediment sample was digested using $15 \mathrm{ml}$ of concentrated $\mathrm{HNO}_{3}$ and $5 \mathrm{ml}$ of $\mathrm{H}_{2} \mathrm{O}_{2}$, and then heated by 2 hours using heating jacket. Once mineralization was accomplished liquid sample was diluted to $50 \mathrm{~cm}^{3}$ using deionized ultrapure water. Water samples were vaporized to 20-25 $\mathrm{cm}^{3}$ and then mineralized using analogical procedure as described above for sediments. All reagents used were of analytical purity. Deionized ultrapure water produced by HLP10 (Hydrolab, Poland) was used. For sample and reference materials preparation the $65 \%$ nitric acid (Merck, Germany) and 30\% hydrogen peroxide (Sigma Aldrich, Germany) were used.

The inductively coupled plasma optical emission spectrometer Agilent 5100 ICP-OES (Agilent, USA) has been used in multielemental determination ( $\mathrm{Al}, \mathrm{B}, \mathrm{Ba}, \mathrm{Bi}$, $\mathrm{Cr}, \mathrm{Cu}, \mathrm{Fe}, \mathrm{Ir}, \mathrm{Mn}, \mathrm{Nd}, \mathrm{Ni}, \mathrm{Pb}, \mathrm{Pr}, \mathrm{Sm}, \mathrm{Sr}, \mathrm{Ti}, \mathrm{TI}, \mathrm{V}, \mathrm{Yb}$ and $\mathrm{Zn}$ ). The synchronous vertical dual view (SVDV) of the plasma has been accomplished by using dichroic spectral combiner (DSC) technology which allows the axial and radial view analysis simultaneously. The common conditions have been used: Radio Frequency (RF) power $1.2 \mathrm{~kW}$, nebulizer gas flow $0.7 \mathrm{~L} \mathrm{~min}^{-1}$, auxiliary gas flow $1.0 \mathrm{~L} \mathrm{~min}{ }^{-1}$, plasma gas flow $12.0 \mathrm{~L} \mathrm{~min}^{-1}$, Charge Coupled Device $(C C D)$ temperature $-40^{\circ} \mathrm{C}$, viewing height for radial plasma observation $8 \mathrm{~mm}$, accusation time $5 \mathrm{~s}, 3$ replicates. For ICP-OES analysis the ICP commercial analytical standards (Romil, England) have been used. The detection limits have been determined as 3-sigma criteria and were on the level of $0.001 \mathrm{mg} \mathrm{L}^{-1}$ and $0.01 \mathrm{mg} \mathrm{kg}^{-1} \mathrm{dry}$ weight (DW) for all elements determined. The uncertainty for complete analytical process (including sample preparation) was at the level of $20 \%$. The standard reference materials CRM S-1 - loess soil; CRM NCSDC (73349) - bush branches and leaves; CRM 2709 - soil; CRM 405 - estuarine sediments and CRM 667- estuarine sediments have been used for analysis quality control. The recovery (80-120\%) was acceptable for all the elements determined. Detailed information concerning analytical procedure has been published before (Siwulski et al., 2017).

\subsection{Data mining techniques}

For overall exploration of the analytical data principal component analysis (PCA) was used, separately for water and bottom sediment data sets, however prior its use the interest of the implementation of the PCA on a dataset was checked by the use of Bartlett's sphericity test. The Bartlett's test compares the observed correlation matrix to the identity matrix. In other words, it checks if there is a certain redundancy between the variables that can be summarized with a few number of principal 
components. If the variables are perfectly correlated, only one factor is sufficient. If they are orthogonal, as many factors as variables are needed. In this last case, the correlation matrix is the same as the identity matrix. Positive checking has allowed an application of PCA. PCA enables the reduction of the dimensionality of the space of the variables in the direction of the highest variance of the system. New variables, called principal components being linear combinations of the previous variables, replace the old coordinates of the factor space. PCA results are indicated by two sets - factor scores giving the new coordinates of the factor space with the location of the objects and factor loadings which provide necessary data concerning the relationship between the variables. In the presented case study factor loadings higher than 0.5 were taken into consideration. Usually, the first principal component explains the maximal part of the system variation and each additional $P C$ has a respective contribution to the variance explanation, however, less significant one when compared to the previous one. A reliable model in environmental studies usually requires such a number of PCs, so that over $70-75 \%$ of the total variation can be explained. Moreover, in the case of presented exploration varimax (as indubitably the most popular rotation method by far (Hervé, 2010) rotated PCA solution was interpreted. Rotation strategy simplifies the structure of factors and therefore makes its interpretation easier and more reliable since it strengthens the role of the latent factors with a higher impact on the variation explanation and diminishes the role of PCs with a lower impact (Cattell, 1978; Thurstone, 1974). The sequence of rotated factors might no longer be arranged in an order of decreasing percentage of variance explained, although the total variance explained is equal before and after rotation. All calculations were performed by the use of the software package STATISTICA 12.0 (Statsoft Inc., USA).

Table 1. Mean concentrations of metals in water $\left(\mathrm{mg} \mathrm{L}^{-1}\right)$ and bottom sediments $\left(\mathrm{mg} \mathrm{kg}^{-1)}\right.$ in ICOLLs of various connectivity with the Baltic Sea

\begin{tabular}{cccccccccc}
\hline & \multicolumn{4}{c}{ Coastal lake water (w) } & \multicolumn{4}{c}{ Bottom sediment (s) } \\
\cline { 2 - 10 } & Mean & Mean(FC) & Mean(PC) & Mean(I) & Mean & Mean(FC) & Mean(PC) & Mean(I) & Ratio s:w \\
\hline $\mathrm{Al}$ & 0.761 & 0.549 & 1.375 & 0.534 & 5143.443 & 4831.386 & 7096.646 & 4119.152 & 6763 \\
\hline $\mathrm{B}$ & 1.379 & 1.220 & 1.403 & 1.473 & 138.198 & 172.703 & 140.178 & 114.873 & 100 \\
\hline $\mathrm{Ba}$ & 0.029 & 0.035 & 0.026 & 0.026 & 50.650 & 20.636 & 120.897 & 25.837 & 1755 \\
\hline $\mathrm{Bi}$ & 0.001 & 0.001 & 0.002 & 0.001 & 20.317 & 21.197 & 24.733 & 16.986 & 14130 \\
\hline $\mathrm{Cr}$ & 0.037 & 0.035 & 0.039 & 0.038 & 26.491 & 16.006 & 55.525 & 12.972 & 713 \\
\hline $\mathrm{Cu}$ & 0.019 & 0.019 & 0.021 & 0.018 & 54.654 & 44.003 & 101.557 & 32.078 & 2855 \\
\hline $\mathrm{Fe}$ & 0.873 & 0.571 & 1.153 & 0.909 & 46949.505 & 53316.316 & 52866.690 & 39166.644 & 53791 \\
\hline $\mathrm{Ir}$ & 0.003 & 0.002 & 0.004 & 0.004 & 14.199 & 15.996 & 14.500 & 12.861 & 4268 \\
\hline $\mathrm{Mn}$ & 0.169 & 0.189 & 0.182 & 0.147 & 3387.995 & 5197.093 & 3816.401 & 1961.705 & 20074 \\
\hline $\mathrm{Nd}$ & 0.012 & 0.006 & 0.016 & 0.014 & 592.710 & 778.411 & 648.068 & 439.170 & 48225 \\
\hline $\mathrm{Ni}$ & 0.067 & 0.045 & 0.098 & 0.063 & 53.893 & 47.345 & 71.052 & 47.331 & 809 \\
\hline $\mathrm{Pb}$ & 0.074 & 0.061 & 0.094 & 0.071 & 52.008 & 45.056 & 70.732 & 44.724 & 705 \\
\hline $\mathrm{Pr}$ & 0.030 & 0.052 & 0.021 & 0.021 & 27.634 & 24.435 & 38.578 & 22.824 & 907 \\
\hline $\mathrm{Sm}$ & 0.010 & 0.006 & 0.012 & 0.012 & 21.345 & 17.361 & 27.118 & 20.277 & 2118 \\
\hline $\mathrm{Sr}$ & 0.572 & 1.280 & 0.163 & 0.285 & 27.809 & 39.630 & 34.155 & 15.036 & 49 \\
\hline $\mathrm{Ti}$ & 0.010 & 0.006 & 0.017 & 0.007 & 168.244 & 149.421 & 200.171 & 157.791 & 17592 \\
\hline $\mathrm{Tl}$ & 0.002 & 0.001 & 0.002 & 0.002 & 62.259 & 62.491 & 75.987 & 52.953 & 40326 \\
\hline $\mathrm{V}$ & 0.010 & 0.008 & 0.012 & 0.009 & 33.985 & 29.096 & 42.796 & 32.224 & 3565 \\
\hline $\mathrm{Yb}$ & 0.001 & 0.001 & 0.001 & 0.001 & 36.497 & 39.879 & 42.040 & 30.671 & 31807 \\
\hline $\mathrm{Zn}$ & 1.003 & 0.791 & 1.241 & 1.004 & 2735.190 & 1860.564 & 5319.676 & 1619.032 & 2727 \\
\hline & & & & & & & & &
\end{tabular}

\section{Results and discussion}

The average concentration of 22 metals in 10 lakes located along the Polish coastline are summarized in Table 1 according to level of lakes isolation towards the Baltic Sea. Moreover, the ratio between metals concentration in water and bottom sediments is given as well. Analytes' abundance shows considerable variation in the concentration along the matrix of the sample. In water mean concentration of $B$ and $\mathrm{Zn}$ was three orders of magnitude higher than $\mathrm{Ir}, \mathrm{Tl}$ and $\mathrm{Yb}$. In bottom sediment samples the highest concentration was determined for Fe and Ho. Excluding seasonal and spatial variation in this stage mean concentration in water decreases in the following order: $\mathrm{B}>\mathrm{Zn}>\mathrm{Fe}>\mathrm{Al}>\mathrm{Sr}>\mathrm{Mn}>$ $\mathrm{Pb}>\mathrm{Ni}>\mathrm{Cr}>\mathrm{Pr}>\mathrm{Ba}>\mathrm{Cu}>\mathrm{Nd}>\mathrm{V}, \mathrm{Ti}, \mathrm{Sm}>\mathrm{Ir}>\mathrm{Tl}>\mathrm{Yb}, \mathrm{Bi}$, while in bottom sediments in the following one: $\mathrm{Ti}>\mathrm{V}>\mathrm{Al}>\mathrm{Cu}>\mathrm{B}>$ $\mathrm{Ba}>\mathrm{Nd}>\mathrm{Sr}>\mathrm{Yb}>\mathrm{Sm}>\mathrm{Pr}>\mathrm{Cr}>\mathrm{Tl}>\mathrm{Zn}>\mathrm{Fe}>\mathrm{Mn}>\mathrm{Ni}>\mathrm{Pb}>\mathrm{Ir}>\mathrm{Bi}$.

Comparing to other brackish lakes in the world (Table 2), the concentration of $\mathrm{Cu}$ in waters of Polish coastal lakes is 4-6 times lower than those in heavily polluted Thaiu lake in China (Rajeshkumar et al., 2018) and being important habitat for artemia and various birds Maharlu lake in Iran (Moore et al., 2009), while comparable to other lakes, especially from Egypt, Ethipia and Nigeria. Similar results were revealed in case of $\mathrm{Pb}$. The concentration of lead in water of Polish lakes is far lower than those in Thaiu and Maharlu lakes, and comparable with Egyptian lakes. The concentration of Fe and $\mathrm{Mn}$ in 10 polish ICOLLs are close to lakes from Egypt and Nigeria, however $\mathrm{Zn}$ concentration is 2-3 times higher than reported for 
Manzala lake in Egipt (Bahnasawy et al., 2011; Saeed and Shaker, 2008), and even 100 times higher in comparison to other Egyptian lake Edku (Saeed and Shaker, 2008) while almost $50 \%$ lower than in previous research conducted in polish Resko lake (Daniszewski and Konieczny, 2013a,b). In the light of available literature uncontested novelty of our paper relies on delivering concentration data for $\mathrm{B}, \mathrm{Bi}, \mathrm{Ir}, \mathrm{Nd}, \mathrm{Pr}, \mathrm{Sm}, \mathrm{Tl}$ and $\mathrm{Yb}$, since none of data for comparison is available in current literature. The higher number of verifiable results are available for metal's concentration in bottom sediments.

The concentration of $\mathrm{Cu}, \mathrm{Pb}, \mathrm{Fe}$ and $\mathrm{Mn}$ in sediments of Polish ICOLLs is of similar order of magnitude than those in Egyptian lakes, excluding Manzala lake (Saeed and Shaker, 2008; Shalaby et al., 2017). Suprisingly, the concentration of $\mathrm{Zn}$ in bottom sediments of polish ICOLLS is 5 up to even 135 times higher than in other lakes, depending on their location. To validate metals' concentration determined in the current study they were compared to average, maximal and minimal values available in FOREGS (Forum of European Geological Surveys) geochemical baseline database (Salminen et al., 2005). In general, the concentrations in FOREGS are in the same range as found in this study, however the levels in the FOREGS database are slightly lower. We assume this is because FOREGS baseline results concern stream waters and sediments while in this study brackish water reservoirs of limited flux were tested, and hence some accumulation phenomenon could take place. Moreover, the sampling sites for the FOREGS database are a result of a random procedure and they rather reflect areas more or less influenced by diffuse pollution (Borg, 2007), and hence they consequenty reflect the present ambient concentrations.

The results revealed that in case of several metals relatively low concentration in water corresponds with high concentration in sediments indicating that some metals are able to be settled and accumulated in the sediments. Assuming water density as $1000 \mathrm{~g} \mathrm{~L}^{-1}$ the highest ratios between sedimental concentration and water concentration were found for $\mathrm{Fe}, \mathrm{Mn}, \mathrm{Nd}, \mathrm{Ti}, \mathrm{TI}$ and $\mathrm{Yb}$. The relationship among geochemical variables in the lakes' sediments and water and the sources of these metals were evaluated by correlation analysis and PCA. The list of metals correlated with each other are summarized in Table 3. A highly significant $(p=0.001)$ correlation coefficients between metals in bottom sediments and waters proved an application of PCA justified and looked promising.

According to the PCA, six and four factors with eigenvalues $>1$ were obtained, accounting for $70.5 \%$ and $77 \%$ of the total variance for water and bottom sediment data sets, respectively. For water data set PCA solution according to the metal contribution and percentage of explained variance was as follows: $\mathrm{F} 1$ : $\mathrm{Al}, \mathrm{Fe}, \mathrm{Mn}, \mathrm{Ti}, \mathrm{V}$ and $\mathrm{Yb}-30.5 \%$; F2: Ir, Nd, Pr(-), Sm, Sr(-) - 16\%; F3: Cu(-), Zn(-) - 7.3\%; F4: B, Bi - 6.1\%, F5: Pb, TI - 5.5\% and F6: $\mathrm{Ba}, \mathrm{Ni}-$
$5.1 \%$. In case of sediments respective composition and percentage of explained variance were as follows: $\mathrm{F} 1$ : $\mathrm{Al}$, $\mathrm{Ba}, \mathrm{Cr}, \mathrm{Cu}, \mathrm{Ni}, \mathrm{Ti}, \mathrm{Zn}-42.2 \%$; 2 : B, Bi, Nd, Sm, Tl, Yb - 18\%; F3: B, Fe, Ir, Mn, Nd, Sm, V - 9.9\%; F4: Pr, Sr - 6.9\%. Negative sign written next to the metal indicates indirectly proportional correlation with the rest of metals included to the particular factor. In the interpretation stage only factor loadings $>0.5$ for particular metal were taken into consideration.

F1 for water, with a variance of $30.5 \%$ and significant contribution of $\mathrm{Al}, \mathrm{Fe}, \mathrm{Mn}, \mathrm{Ti}, \mathrm{V}$ and $\mathrm{Yb}$ indicates semi natural background related to purification of water taken from underground wells (Astel et al., 2006). F2 for water, with a variance of $16 \%$, highly correlated with Ir, Nd, Sm with negative correlation of $\mathrm{Pr}$ and $\mathrm{Sr}$ indicates mineralogical origin, since both samarium and neodymium are abundant in crustal rocks (around 6000 and 33000 ppb by weight, respectively for Sm and Nd). F3 for water, with a variance of $7.3 \%$ and correlation of $\mathrm{Cu}$ and $\mathrm{Zn}$ indicates the anthropogenic impact related to application of pigments as wood preservatives (Akhtari and Nicholas, 2013). Both F4 and F5 for water, with a variance $6.1 \%$ and $5.5 \%$ respectively indicate geochemical background. F6 for water, with a variance of $5.1 \%$ and correlation of $\mathrm{Ba}$ and $\mathrm{Ni}$ refers to processes of interaction between discharging groundwater, sea-water intrusions and bottom sediments (Batoyan and Brusilovsky, 1976).

F1 for bottom sediments, with a variance of $42.2 \%$, highly correlated with $\mathrm{Al}, \mathrm{Ba}, \mathrm{Cr}, \mathrm{Cu}, \mathrm{Ni}, \mathrm{Ti}$ and $\mathrm{Zn}$, indicates the anthropogenic factor related to pigments, electroplating, gasoline and domestic wastewater (Lin and Hsieh, 2002). F2, which accounted $18 \%$ of the total variance, correlated with $\mathrm{B}, \mathrm{Bi}, \mathrm{Nd}, \mathrm{Sm}, \mathrm{Tl}$ and $\mathrm{Yb}$, indicates mineralogical impact of discharge from crustal rocks. F3 for sediments, with a variance of $9.9 \%$ and correlation of $\mathrm{B}, \mathrm{Fe}, \mathrm{Ir}, \mathrm{Mn}$, $\mathrm{Nd}, \mathrm{Sm}$ and $\mathrm{V}$, assembles of metals characterizing the semi natural background mentioned above. The last, F4 for sediments contributes only $6.9 \%$ of the total variance and being correlated with $\mathrm{Pr}$ and $\mathrm{Sr}$ probably indicates rare earth elements leaching from Cretaceous deposits (Baioumy, 2011).

The relation between identified factors and ICOLLs types as well as seasonality was identified by the visualization of factor scores in various combinations of factors. Convergent signs of factor scores and correlations between variable contributed to a factor indicates directly proportional relation. It means the higher positive value of the factor score the higher impact (in terms of concentration) of positively correlated variable with the factor on the sample. On the contrary, the higher positive value of the factor score the lower impact of negatively correlated variable with the factor on the sample. Plot of sample scores of F1 vs F2, F3 vs F4 and F5 vs F6 for waters visualized according to the lakes, including its connectivity with the Baltic Sea is presented on Figure 2-4, while plot of sample scores of F1 vs F2 and F3 vs F4 for bottom sediments visualized according to analogous criteria and additionally seasonality is presented on Figure 5 and 6 . 
Table 2. Comparison of the concentration of metals in water and bottom sediments of 10 Polish coastal lakes to other lakes in the world

\begin{tabular}{|c|c|c|c|c|c|c|c|c|c|c|c|c|c|}
\hline Lake & Al & $\mathrm{Ba}$ & $\mathrm{Cr}$ & $\mathrm{Cu}$ & $\mathrm{Fe}$ & $\mathrm{Mn}$ & $\mathrm{Ni}$ & $\mathbf{P b}$ & Sr & $\mathrm{Ti}$ & $\mathbf{v}$ & $\mathrm{Zn}$ & References \\
\hline Uburu9 & 9.28 & & 14.75 & 9.61 & 1428 & 101.60 & & 17.45 & & & & 54.85 & $\begin{array}{l}\text { Akubugwo } \\
\text { et al., } 2007\end{array}$ \\
\hline Maharlu10 & 20131 & & 40.21 & 38.14 & 19476.73 & 554.41 & 206.99 & 160.26 & & & & 67.35 & Moore et al., 2009 \\
\hline \multicolumn{14}{|c|}{ lake water $\left(\mathrm{mg} \mathrm{L}^{-1}\right)$} \\
\hline Chamo $^{11}$ & & & & 0.05 & & & & & & & & 0.21 & Tafa and Assefa, 2014 \\
\hline Thaiu $^{4}$ & & & 0.9 & 0.49 & & & & 13.4 & & & & & Rajeshkumar et al., 2018 \\
\hline Pulicat $^{5}$ & & & 5.6 & & & & & 2.89 & & & & & $\begin{array}{l}\text { Kamala-Kannan } \\
\text { et al., } 2008\end{array}$ \\
\hline \multirow[t]{2}{*}{ Manzala $^{3}$} & & & & 0.055 & & & & 0.022 & & & & 0.311 & $\begin{array}{l}\text { Bahnasawy } \\
\text { et al., } 2011\end{array}$ \\
\hline & & & & 0.51 & 1.42 & 0.51 & & 0.099 & & & & 0.46 & \multirow{3}{*}{ Saeed and Shaker, 2008} \\
\hline $\mathrm{Edku}^{3}$ & & & & 0.011 & 0.570 & 0.024 & & 0.028 & & & & 0.016 & \\
\hline Burulus $^{3}$ & & & & 0.035 & 0.425 & 0.194 & & 0.065 & & & & 0.050 & \\
\hline Uburu $^{9}$ & 0.062 & & 0.050 & 0.015 & 0.240 & 1.32 & & & & & & 0.036 & $\begin{array}{l}\text { Akubugwo } \\
\text { et al., } 2007\end{array}$ \\
\hline Maharlu10 & & & & 0.28 & 10.4 & 1.5 & 2.36 & 5.17 & & & & 0.37 & Moore et al., 2009 \\
\hline \multirow{2}{*}{ Resko $^{7}$} & & & 1.75 & 0.05 & & & 2.07 & 0.07 & & & & 3.02 & $\begin{array}{l}\text { Daniszewski and } \\
\text { Konieczny, 2013a }\end{array}$ \\
\hline & & & 1.97 & 0.06 & & & 2.09 & 0.05 & & & & 2.74 & $\begin{array}{c}\text { Daniszewski and } \\
\text { Konieczny, 2013b }\end{array}$ \\
\hline \multicolumn{14}{|c|}{ Bottom sediment ( $\left.\mathrm{mg} \mathrm{kg}^{-1} \mathrm{~d} . \mathrm{w}.\right)$} \\
\hline Aheme $^{1}$ & & & & & 4957.04 & & & 36.61 & & & & 171.37 & Oumar et al., 2014 \\
\hline Bini $^{2}$ & & & & & 87033.56 & & & 65.43 & & & & 43.52 & $\begin{array}{l}\text { Hounkpe } \\
\text { et al., } 2017\end{array}$ \\
\hline \multirow{3}{*}{ Burulus $^{3}$} & & & & 47.49 & 10999.49 & 850.95 & & 13.08 & & & & 217.33 & Saeed and Shaker, 2008 \\
\hline & & 380.87 & 131.50 & 50.19 & & & 58.38 & 8.88 & 285.31 & & 208.69 & 83.25 & $\begin{array}{c}\text { Samy and } \\
\text { El-Bady, } 2014\end{array}$ \\
\hline & & & & 59.81 & 27.68 & 1148.09 & & 17.85 & & & & 94.33 & Shalaby et al., 2017 \\
\hline Bardawil $^{3}$ & & 283.42 & 11.77 & 10.54 & & & 8.77 & 9.62 & 254.46 & & 21.38 & 20.46 & $\begin{array}{l}\text { Samy and } \\
\text { El-Bady, } 2014\end{array}$ \\
\hline $\mathrm{Aibi}^{3}$ & 53.16 & & 51.49 & 39.89 & & & 28.27 & 39.57 & & & & 114.59 & $\begin{array}{l}\text { Abuduwaili } \\
\text { et al., } 2015\end{array}$ \\
\hline \multirow{3}{*}{ Manzala $^{3}$} & 24.83 & 121.1 & 18.7 & 14.04 & 23.69 & 416.62 & 14.82 & 49.49 & 996.5 & & 26.5 & 63.75 & Elkady et al., 2015 \\
\hline & & & & 315.36 & 33386.64 & 419.6 & & 134.6 & & & & 432.16 & Saeed and Shaker, 2008 \\
\hline & & & & 380.45 & 37.3 & 1550 & & 146.85 & & & & 512.16 & $\begin{array}{l}\text { Shalaby } \\
\text { et al., } 2017\end{array}$ \\
\hline \multirow[b]{2}{*}{$\mathrm{Edku}^{3}$} & & & & 36.77 & 6253.99 & 1390.13 & & 193.25 & & & & 344.45 & Saeed and Shaker, 2008 \\
\hline & & & & 41.56 & 25.46 & 1200 & & 31.7 & & & & 352 & $\begin{array}{c}\text { Shalaby } \\
\text { et al., } 2017\end{array}$ \\
\hline Hamara $^{3}$ & & & & 65.5 & & 605.5 & 27 & 51.83 & & & & 57.66 & \multirow{3}{*}{ Taher and Soliman, 1999} \\
\hline Khadra $^{3}$ & & & & 27.33 & & 84.66 & 25 & 50.33 & & & & 34.33 & \\
\hline Beida $^{3}$ & & & & 32.4 & & 204 & 26.8 & 53.2 & & & & 37.2 & \\
\hline Quaroun $^{3}$ & & & 124.89 & 38.91 & & & 54.74 & 14.21 & & & 193.90 & 77.21 & $\begin{array}{c}\text { El-Sayed } \\
\text { et al., } 2015\end{array}$ \\
\hline Thaiu $^{4}$ & & & 79.8 & 37.4 & & & & 40.2 & & & & 96.70 & Yuan et al., 2014 \\
\hline \multirow{2}{*}{ Pulicat $^{5}$} & 21200 & & 27.30 & & 6500 & 115.90 & 16.40 & & & 1700 & 41.40 & 22.40 & $\begin{array}{l}\text { Tholkappian } \\
\text { et al., } 2018\end{array}$ \\
\hline & & & 28.51 & & & & & 8.32 & & & & & $\begin{array}{l}\text { Kamala-Kannan } \\
\text { et al., } 2008\end{array}$ \\
\hline Shihwa ${ }^{6}$ & & & 93.3 & 129 & & 489 & 37.3 & 56 & & & & 253 & Kim et al., 2009 \\
\hline $\mathrm{Tuz}^{8}$ & & & 50.59 & 28.18 & & & 75 & 9.84 & & & & 45.16 & Tug and Duman, 2010 \\
\hline
\end{tabular}

${ }^{1}$ West Africa, ${ }^{2}$ Cameroun, ${ }^{3}$ Egypt, ${ }^{4}$ China, ${ }^{5}$ India, ${ }^{6}$ South Korea, ${ }^{7}$ Poland, ${ }^{8}$ Turkey, ${ }^{9}$ Nigeria, ${ }^{10}$ Iran, ${ }^{11}$ Ethiopia 


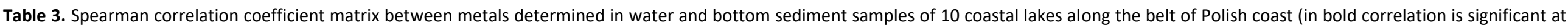
the 0.001 level; upper right part of the matrix concerns bottom sediments while lower left concerns water samples)

\begin{tabular}{|c|c|c|c|c|c|c|c|c|c|c|c|c|c|c|c|c|c|c|c|c|}
\hline & $\mathrm{Al}$ & B & Ba & $\mathrm{Bi}$ & $\mathrm{Cr}$ & $\mathrm{Cu}$ & $\mathrm{Fe}$ & Ir & $\mathrm{Mn}$ & $\mathrm{Nd}$ & $\mathrm{Ni}$ & $\mathrm{Pb}$ & $\mathrm{Pr}$ & $\mathrm{Sm}$ & $\mathrm{Sr}$ & $\mathrm{Ti}$ & $\mathrm{TI}$ & $v$ & $\mathrm{Yb}$ & $\mathrm{Zn}$ \\
\hline $\mathrm{Al}$ & - & 0.86 & 0.93 & 0.78 & 0.63 & 0.88 & 0.54 & 0.77 & 0.48 & 0.66 & 0.74 & 0.55 & 0.86 & 0.64 & -0.09 & 0.65 & 0.25 & 0.26 & 0.69 & 0.52 \\
\hline $\mathrm{B}$ & 0.54 & - & 0.77 & 0.83 & 0.57 & 0.81 & 0.55 & 0.82 & 0.47 & 0.67 & 0.66 & 0.49 & 0.82 & 0.59 & -0.11 & 0.52 & 0.27 & 0.29 & 0.65 & 0.49 \\
\hline $\mathrm{Ba}$ & 0.04 & 0.15 & - & 0.80 & 0.59 & 0.86 & 0.52 & 0.74 & 0.47 & 0.66 & 0.71 & 0.52 & 0.87 & 0.64 & -0.10 & 0.65 & 0.25 & 0.28 & 0.65 & 0.52 \\
\hline $\mathrm{Bi}$ & 0.30 & 0.29 & -0.30 & - & 0.49 & 0.82 & 0.45 & 0.77 & 0.37 & 0.64 & 0.63 & 0.57 & 0.78 & 0.50 & -0.10 & 0.44 & 0.34 & 0.22 & 0.65 & 0.39 \\
\hline $\mathrm{Cr}$ & -0.06 & -0.25 & -0.17 & 0.28 & - & 0.63 & 0.87 & 0.77 & 0.81 & 0.23 & 0.45 & 0.32 & 0.65 & 0.17 & 0.25 & 0.79 & -0.10 & 0.50 & 0.10 & 0.86 \\
\hline $\mathrm{Cu}$ & 0.49 & 0.39 & 0.09 & 0.09 & -0.31 & - & 0.46 & 0.79 & 0.38 & 0.61 & 0.70 & 0.59 & 0.80 & 0.55 & -0.03 & 0.56 & 0.34 & 0.18 & 0.70 & 0.46 \\
\hline $\mathrm{Fe}$ & 0.83 & 0.35 & -0.19 & 0.39 & 0.12 & 0.36 & - & 0.60 & 0.92 & 0.18 & 0.29 & 0.23 & 0.61 & 0.23 & 0.19 & 0.66 & $\begin{array}{r}-0.52 \\
\end{array}$ & 0.73 & -0.05 & 0.94 \\
\hline $\mathrm{Ir}$ & 0.25 & 0.12 & -0.35 & 0.31 & 0.26 & 0.13 & 0.37 & - & 0.51 & 0.54 & 0.61 & 0.41 & 0.74 & 0.45 & 0.06 & 0.79 & 0.17 & 0.29 & 0.54 & 0.53 \\
\hline $\mathrm{Mn}$ & 0.57 & 0.28 & 0.37 & 0.05 & 0.03 & 0.23 & 0.51 & 0.05 & - & 0.27 & 0.29 & 0.24 & 0.58 & 0.27 & 0.03 & 0.55 & -0.54 & 0.83 & -0.13 & 0.90 \\
\hline $\mathrm{Nd}$ & 0.46 & 0.16 & -0.52 & 0.60 & 0.38 & 0.12 & 0.63 & 0.62 & 0.04 & - & 0.73 & 0.58 & 0.58 & 0.82 & -0.56 & 0.31 & 0.42 & 0.36 & 0.69 & 0.16 \\
\hline $\mathrm{Ni}$ & -0.06 & -0.17 & -0.21 & 0.20 & 0.56 & -0.21 & 0.12 & 0.23 & -0.10 & 0.29 & - & 0.61 & 0.67 & 0.67 & -0.13 & 0.43 & 0.33 & 0.30 & 0.71 & 0.33 \\
\hline $\mathrm{Pb}$ & 0.34 & 0.23 & -0.05 & 0.10 & -0.27 & 0.33 & 0.35 & 0.07 & 0.21 & 0.18 & -0.20 & - & 0.50 & 0.42 & -0.22 & 0.22 & 0.27 & 0.30 & 0.46 & 0.23 \\
\hline $\mathrm{Pr}$ & -0.05 & 0.13 & 0.68 & -0.51 & -0.46 & 0.15 & -0.33 & -0.58 & 0.22 & -0.83 & -0.35 & -0.08 & - & 0.47 & 0.09 & 0.56 & 0.13 & 0.40 & 0.53 & 0.59 \\
\hline $\mathrm{Sm}$ & 0.16 & 0.03 & -0.63 & 0.55 & 0.44 & -0.09 & 0.37 & 0.60 & -0.18 & 0.86 & 0.31 & 0.04 & -0.92 & - & -0.60 & 0.26 & 0.28 & 0.32 & 0.63 & 0.25 \\
\hline $\mathrm{Sr}$ & -0.24 & -0.04 & 0.58 & -0.60 & -0.46 & 0.02 & -0.43 & -0.58 & 0.01 & -0.90 & -0.34 & -0.09 & 0.92 & -0.91 & - & 0.13 & -0.25 & -0.18 & -0.22 & 0.16 \\
\hline $\mathrm{Ti}$ & 0.93 & 0.44 & 0.03 & 0.33 & -0.05 & 0.38 & 0.76 & 0.33 & 0.46 & 0.52 & -0.08 & 0.30 & -0.14 & 0.25 & -0.31 & - & 0.14 & 0.21 & 0.32 & 0.62 \\
\hline $\mathrm{TI}$ & -0.00 & -0.11 & -0.07 & 0.01 & 0.12 & -0.06 & 0.03 & 0.05 & -0.00 & 0.17 & 0.10 & 0.05 & -0.16 & 0.11 & -0.08 & 0.01 & - & -0.60 & 0.71 & -0.55 \\
\hline $\mathrm{v}$ & 0.83 & 0.47 & -0.05 & 0.36 & 0.08 & 0.44 & 0.84 & 0.35 & 0.56 & 0.56 & 0.04 & 0.36 & -0.24 & 0.30 & -0.39 & 0.85 & 0.06 & - & -0.21 & 0.72 \\
\hline $\mathrm{Yb}$ & 0.81 & 0.36 & -0.27 & 0.45 & 0.11 & 0.33 & 0.92 & 0.42 & 0.41 & 0.74 & 0.09 & 0.37 & -0.43 & 0.50 & -0.54 & 0.81 & 0.08 & 0.84 & - & -0.02 \\
\hline $2 n$ & 0.21 & 0.15 & -0.17 & 0.09 & 0.03 & 0.27 & 0.29 & 0.24 & 0.08 & 0.23 & 0.15 & 0.25 & -0.18 & 0.15 & -0.16 & 0.31 & 0.04 & 0.18 & 0.25 & \\
\hline
\end{tabular}




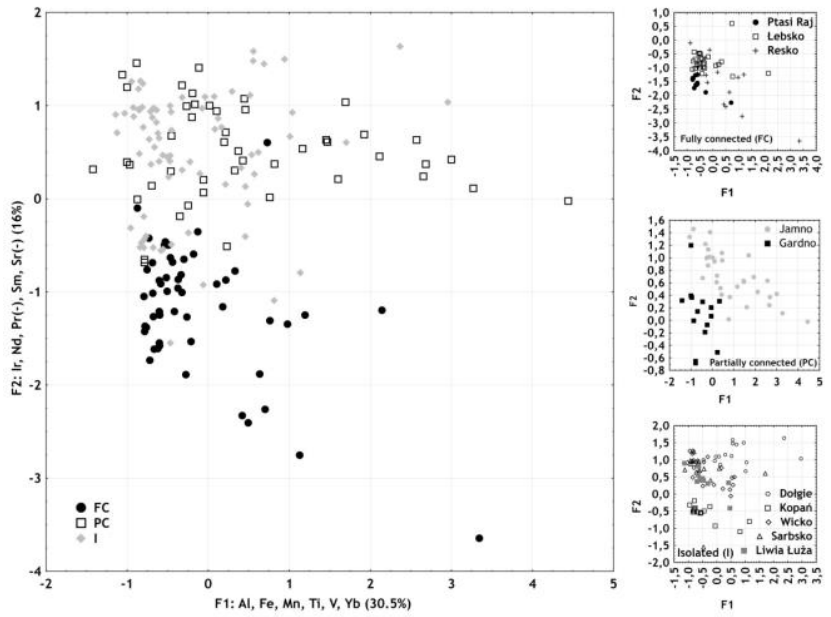

Figure 2. $\mathrm{F} 1$ ( $\mathrm{Al}, \mathrm{Fe}, \mathrm{Mn}, \mathrm{Ti}, \mathrm{V}$ and $\mathrm{Yb}$ ) and $\mathrm{F} 2$ ( $\mathrm{Ir}, \mathrm{Nd}, \mathrm{Sm}, \mathrm{Pr}$ and $\mathrm{Sr}$ ) scores according to level of isolation (FC - fully connected,

PC - partially connected, I - isolated) of ICOLLS

As could be seen on Figure 2 F2 differentiates waters of fully connected lakes from partially connected and isolated. The location of samples along F2 axis proves that water from fully connected reservoirs is not as rich in Ir, $\mathrm{Nd}$ and $\mathrm{Sm}$ as those collected from partially connected or isolated coastal lakes and lagoons. Reversed characteristic is observed for Pr and Sr. It fits with the expectations since closed or periodically open reservoirs are much more susceptible for accumulation of metals $(\mathrm{Nd}, \mathrm{Sm})$ of mineralogical origin. Except for samples from Resko lake water collected from FC lakes create rather homogenous group, while those from $P C$ and I lakes are spread, especially according to concentration of $\mathrm{Al}, \mathrm{Fe}, \mathrm{Mn}, \mathrm{Ti}, \mathrm{V}$ and $\mathrm{Yb}$. The highest dispersion along F2 axis is observed for Jamno indicating substantial anthropogenic impact due to water treatment plant operating nearby. Jamno lake is fed by Dzierżęcinka stream, major receiver of effluence from mentioned plant for Koszalin, which is supplied in drinking water coming from Tertiary and Cretaceous underground springs located in Mostowo. Before being introduced to the water distribution system, raw water is deironized and demanganized. As a consequence, $\mathrm{Fe}$ and $\mathrm{Mn}$ are immobilized on the periodically backwashed absorption filters. After backwashing, the wastewater is dumped into the Dzierżęcinka river. That is why increased contents of Fe and $\mathrm{Mn}$ are observed in water collected in Jamno lake.

Careful inspection of Figure 3 proves that, except for 9 samples located mainly on the left side from the dominant "cloud", ICOLLs samples create relatively homogeneous and overlapping group. It suggests substantial similarity and seasonal independence of coastal lakes according to concentration of $\mathrm{Cu}, \mathrm{Zn}, \mathrm{B}$ and $\mathrm{Bi}$. However, Figure 3 also revealed some unexpected sources of water contamination. F3 clearly distinguishes a single samples from Jamno, Gardno and Sarbsko lakes, which were collected mainly in Spring and Autumn, characterized by high $\mathrm{Cu}$ and $\mathrm{Zn}$ concentration. Since the belt of northern Poland is a region free from commercial smelters and mines, which are commonly recognized as source of anthropogenic $\mathrm{Zn}$, detailed inspection of sampling places became necessary. It revealed that, due to extraordinary natural and touristic values, some small wooden playgrounds or camping places were installed by local authorities in the close vicinity of water line. Surprisingly, installation of wooden swings and benches can explain local contamination by $\mathrm{Zn}$, since such installation have to be preserved prior touristic season and winter against pests by the use of fertilizers and wood preservatives containing zinc.

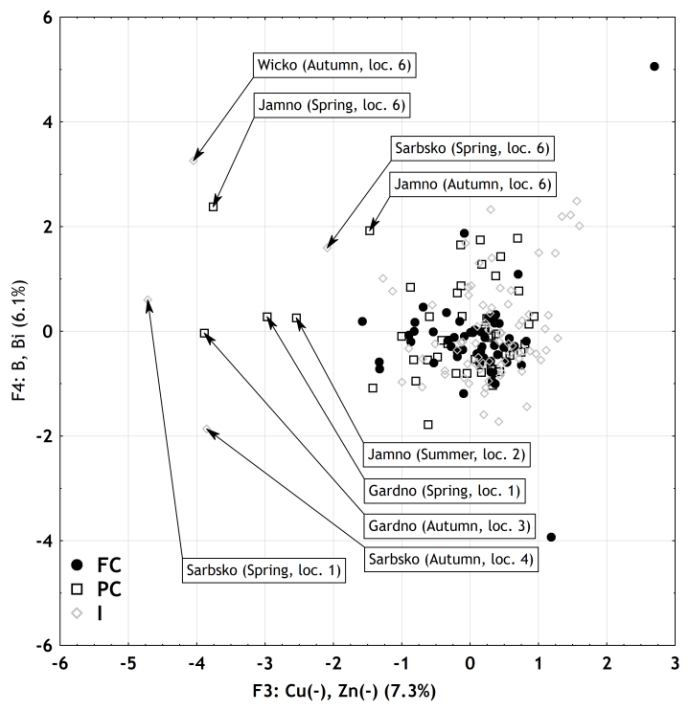

Figure 3. $\mathrm{F} 3(\mathrm{Cu}, \mathrm{Zn})$ and $\mathrm{F} 4(\mathrm{~B}, \mathrm{Bi})$ scores according to level of isolation of ICOLLS

Similar as above, ICOLLs' relation to the Baltic Sea, as well as seasonality, do not play any significant role in diversification of them according to $\mathrm{Pb}, \mathrm{Tl}$ and $\mathrm{Ba}$ concentration, since dominant "cloud" of points represents samples collected from all types of ICOLLs (Figure 4).

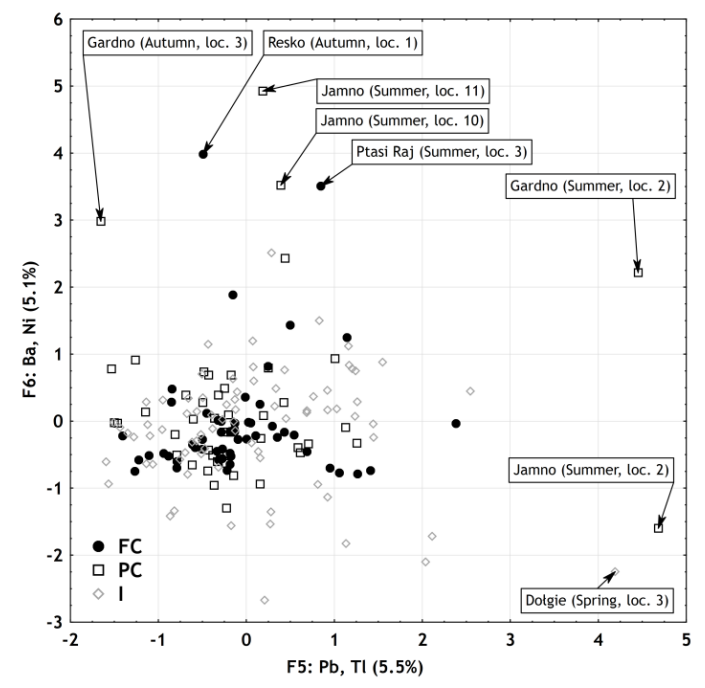

Figure 4. $\mathrm{F} 5(\mathrm{~Pb}, \mathrm{Tl})$ and $\mathrm{F} 6(\mathrm{Ba})$ scores according to level of isolation of ICOLLS 


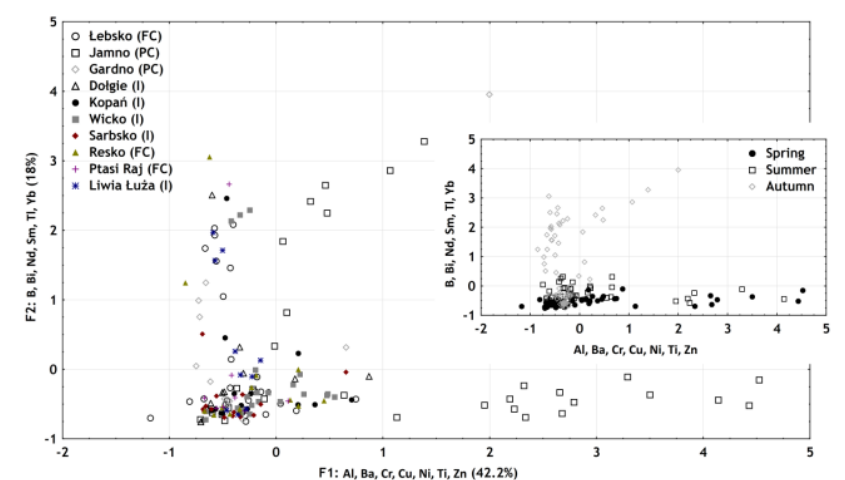

Figure 5. $\mathrm{F} 1$ ( $\mathrm{Al}, \mathrm{Ba}, \mathrm{Cr}, \mathrm{Cu}, \mathrm{Ni}, \mathrm{Ti}$ and $\mathrm{Zn}$ ) and $\mathrm{F} 2(\mathrm{~B}, \mathrm{Bi}, \mathrm{Nd}, \mathrm{Sm}, \mathrm{Tl}$ and $\mathrm{Yb}$ ) scores according to seasonality and level of connectivity (FC - fully connected, PC - partially connected, I - isolated) of ICOLLS

Having in mind that F5 and F6 explain only $10.6 \%$ of the total variance of the system (around $5.5 \%$ each of them) both factors explain variation of a single samples: three samples of the highest concentration of $\mathrm{Pb}$ and $\mathrm{Tl}$ and five samples of the highest concentration of $\mathrm{Ba}$ and $\mathrm{Ni}$. Two of three samples characterized by the highest concentration of $\mathrm{Pb}$ and $\mathrm{Tl}$ were collected in the centre of the lake in summer, while three of five samples characterized by the highest concentration of $\mathrm{Ba}$ and $\mathrm{Ni}$ were collected close to the bank in summer. Such phenomenon suggests that $\mathrm{Ba}$ and $\mathrm{Ni}$ immobilized in bottom sediments could be occasionally discharged to the water body due to processes of interaction between sea water intrusions and sediments. According to Batoyan and Brusilovsky (1976) in the area of fresh groundwater discharge barium and nickel in the bottom sediments is more than twice as much as background concentration, which is due to the processes of interaction between discharging groundwater, bottom sediments and seawater. This is why in coastal zone, particularly in case of fully or partially connected ICOLLs, interaction between bottom sediment and seawater is reasonable. Barium and nickel could be released to water body when salinity and temperature equilibrium disturbance take place, however precise explanation should involve analysis of local stratigraphy and sediment's quality.

In contrast to water samples an abundance of heavy metals in bottom sediments shows significantly higher seasonal dependency. Dispersion of points presented on Figure 5 clearly distinguishes samples collected in Jamno lake which is partially connected with the Baltic Sea. In this specific case the connection is artificially limited by a storm gate built to protect ecological habitats of the lake (Hesse et al., 2013). Position of sediments taken from Jamno lake along F1 characterized by factor scores much higher than 1 proves significant contamination by heavy metals of the highest environmental concern ( $\mathrm{Al}, \mathrm{Cr}, \mathrm{Cu}$, $\mathrm{Ni}, \mathrm{Ti}$ and $\mathrm{Zn}$ ) in comparison with all other sediments. For particular metals mentioned concentration increase was as follows: $1.37-1.86$ for $\mathrm{Al}, \mathrm{Bi}, \mathrm{Ni}, \mathrm{Pb}$ and $\mathrm{Ti} ; 3.23$ for $\mathrm{Cu}$, 4.22 for $\mathrm{Zn}$ and 5.32-5.76 for $\mathrm{Cr}$ and $\mathrm{Ba}$. Observed pattern confirms that aquatic ecosystems' pollution by heavy metals is mainly due to anthropogenic pressure and is not related to the level of isolation of the given lake towards the Baltic Sea. Position of samples collected both, in fully connected and isolated lakes along $\mathrm{F} 1$, proves that these sediments were not as rich in $\mathrm{Al}, \mathrm{Ba}, \mathrm{Cr}, \mathrm{Cu}, \mathrm{Ni}, \mathrm{Ti}$ and $\mathrm{Zn}$ as these collected in Jamno lake. Among of investigated coastal lakes only Jamno lake receives polluted waters discharged by Dzierżęcinka stream flowing through Koszalin city which is one of the biggest cities in central Pomerania region with moderate industry (i.e. building cranes, car laminated glasses, vacuum equipment, sugar and meat factories as well as plastic plants). Such conclusion is reasonable since projection of factor scores of fully connected and isolated lakes on F1 varies in the range between -1 and +1 indicating negligible influence of F1, which meaning in this case refers to heavy metals abundance. Figure 5 reveals an extraordinary seasonal variation of $\mathrm{B}, \mathrm{Bi}, \mathrm{Nd}, \mathrm{Sm}, \mathrm{Tl}$ and $\mathrm{Yb}$ concentration in bottom sediments of several Polish coastal lakes. Majority of samples projected along $\mathrm{F} 2$ and characterized by highly positive factor scores were collected in Autumn (including those from Jamno lake). The characteristic feature of this part of the year on Polish coast is occurrence of heavy storms caused by strong western winds (Merchel, 2014). Winds of high velocity accompanied by sea storms cause not only the backflow of river water in coastal areas and changes in water levels in other coastal water reservoirs, they also induce the phenomena of underground sea water intrusions through crustal rocks. Sea water intrusions are defined as the penetration of sea water into coastal water-bearing layers and bodies of surface water that have a permanent or temporary linkage to the sea. As a result of the intrusion of sea water, these types of aquatic ecosystems experience sudden increase in the concentration of selected chemical entities (Cieśliński et al., 2009) leached from lithosphere. Since concentration of $\mathrm{B}, \mathrm{Bi}, \mathrm{Nd}, \mathrm{Sm}, \mathrm{Tl}$ and $\mathrm{Yb}$ in sea water is measured usually as $\mathrm{ng} \mathrm{kg}^{-1}$ (GERM, 2017) sea water could not be a dominant source of these metals in sediments, however we suppose when intrusion event occurs process of interaction between sea water and crustal rocks takes place and moreover inflow of sea water causes vertical, turbulent mixing of sediments. As result sediments rich in $\mathrm{B}, \mathrm{Bi}, \mathrm{Nd}, \mathrm{Sm}, \mathrm{Tl}$ and $\mathrm{Yb}$ are easily accessible in Autumn.

Similar interesting seasonal variation is revealed by factors scores dispersion presented on Figure 6. As could be seen bottom sediments collected from lakes of various connectivity towards the Baltic Sea create rather overlapping cloud, however some slight diversification appears according to seasonality.

Sediments collected in summer were more abundant with metals located close to each other in the periodic table (V, $\mathrm{Fe}$ and $\mathrm{Mn}$ ) and lanthanides ( $\mathrm{Nd}, \mathrm{Sm}$ ) than samples collected in spring, which were more abundant with $\mathrm{Pr}$ and Sr. It suggests that mutual equilibrium of metals' concentration depends on seasonal modification caused by changes of temperature, external inflow of sea water as well as vertical, turbulent mixing of sediment layers due 
to wave motion. Moreover, in case of fully connected lakes (in particular Resko and Łebsko) high concentration of $\mathrm{Fe}$ and $\mathrm{Mn}$ in water corresponds with high concentration in sediments.

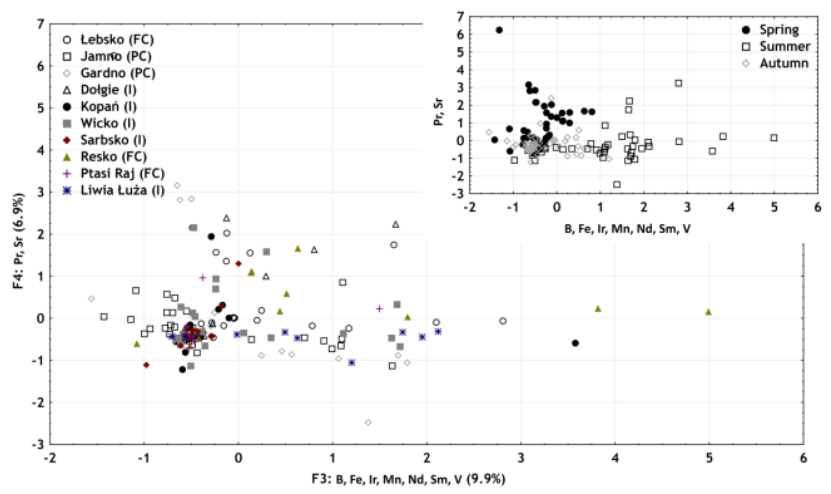

Figure 6. $\mathrm{F} 3$ (B, Fe, Ir, Mn, Nd, Sm and V) and F4 ( $\mathrm{Pr}$ and $\mathrm{Sr}$ ) scores according to seasonality and level of isolation (FC - fully connected, PC - partially connected, I - isolated) of ICOLLs

\section{Conclusions}

This study demonstrates the characteristic of pollution from 20 metals such as $\mathrm{Al}, \mathrm{B}, \mathrm{Ba}, \mathrm{Bi}, \mathrm{Cr}, \mathrm{Cu}, \mathrm{Fe}, \mathrm{Ir}, \mathrm{Mn}, \mathrm{Nd}$, $\mathrm{Ni}, \mathrm{Pb}, \mathrm{Pr}, \mathrm{Sm}, \mathrm{Sr}, \mathrm{Ti}, \mathrm{Tl}, \mathrm{V}, \mathrm{Yb}$ and $\mathrm{Zn}$ in ten ICOLLs spread in along the belt of Polish coast for the first time. The concentration and risk of these metals were affected by human activities, background content, interaction processes between sea-water intrusions and bottom sediments, and seasonality. In general the concentrations determined in this study fit well with geochemical baseline database. The principal component analysis showed slightly different grouping pattern for waters and bottom sediment, however important factors impacting water and sediments quality are: (1) removal of seminatural compounds ( $\mathrm{Fe}, \mathrm{Mn}$ ) by municipal water treatment plants located in the vicinity of feeding rivers; (2) local contamination caused by touristic equipment preservation against pests; (3) discharge of metals immobilized in bottom sediments or leaching from crustal rocks due to interaction processes between sea-water intrusions and water/sediments eguilibrium present in coastal lakes.

\section{Acknowledgements}

This study was supported financially by the National Science Centre, grant no. UMO-2012/07/B/ST10/04359.

\section{References}

Abuduwaili J., Zhang Z.Y. and Jiang F.Q. (2015), Assessment of the distribution, sources and potential ecological risk of heavy metals in the dry surface sediment of Aibi Lake in Northwest China, PLOS ONE, 10(3), e0120001.

Akhtari M. and Nicholas D. (2013), Evaluation of particulate zinc and copper as wood preservatives for termite control, European Journal of Wood and Wood Products, 71(3), 395396.

Akubugwo I.E., Ofoegbu C.J. and Ukwuoma C.U. (2007), Physicochemical studies on Uburu Salt Lake Ebonyi State Nigeria, Pakistan Journal of Biological Sciences, 10(18), 31703174.
Astel A., Głosińska G., Sobczyński T., Boszke L., Simeonov V. and Siepak J. (2006), Chemometrics in assessment of sustainable development rule implementation, Central European Journal of Chemistry, 4(3), 543-564.

Astel A., Bigus K., Obolewski K. and Glińska-Lewczuk K. (2016), Spatiotemporal assessment of water chemistry in intermittently open/closed coastal lakes of southern Baltic, Estuarine, Coastal and Shelf Science, 182, 47-59.

Bahnasawy M., Khidr A.A. and Dheina N. (2009), Assessment of heavy metal concentrations in water, plankton and fish of Lake Manzala, Egypt, Turkish Journal of Zoology, 13(2), 117-133.

Baioumy H. (2011), Rare earth elements and sulfur and strontium istopotes of upper Cretaceous phosphorites in Egypt, Cretaceous Research, 32(3), 368-377.

Batoyan V.V. and Brusilovsky S.A. (1976), Fresh water on the bottom of the Black Sea, Priroda 2, 7-22.

Borg H. (2007), Annex 2: Fact sheet 2 - "Exposure assessment", In: Critical Review of "Metals Environmental Risk Assessment Guidance for Metals" (MERAG), Parkman H. (Ed.), Ekspressen tryk \& Kopicenter, Denmark.

Cattell R.B. (1978), The Scientific Use of Factor Analysis in Behavioral and Life Sciences, Plenum Press, New York.

Carral E., Villares R., Puente X. and Carballeira A. (1995), Influence of watershed lithology on heavy metal levels in estuarine sediments and organisms in Galicia (northwest Spain), Marine Pollution Bulletin, 30, 604-608.

Cieśliński R. (2003), Influence of catchment on trends in nitrates and phosphates concentrations in waters of lake Gardno, Limnological Review, 3, 41-46.

Cieśliński R. (2009), Extreme changes in salinity levels in the waters of coastal lakes in Poland, Limnological Review, 9(2-3), 73-80.

Cieśliński R., Drwal J. and Chlost I. (2009), Sea water intrusion to the lake Gardno, Baltic Coastal Zone, 13, 85-98.

Daniszewski P. and Konieczny R. (2013), Heavy metal content in water of Resko lake (North-West Poland), International Letters of Chemistry, Physics and Astronomy, 8(3), 279-287.

Elkady A.A., Sweet S.T., Wade T.L. and Klein A.G. (2015), Distribution and assessment of heavy metals in the aquatic environment of Lake Manzala, Egypt, Ecological Indicators, 58, 445-457.

El-Sayed S.A., Moussa E.M.M. and El-Sabagh M.E.I. (2015), Evaluation of heavy metal content in Qaroun Lake, El-Fayoum, Egypt. Part I: Bottom sediments, Journal of Radiation Research and Applied Sciences, 8, 276-285.

Fujita M., Ide Y., Sato D., Kench P.S., Kuwahara Y., Yokoki H. and Kayanne H. (2014), Heavy metal contamination of coastal lagoon sediments: Fongafale Islet, Funafuti Atoll, Tuvalu, Chemosphere, 95, 628-634.

GERM (Geochemical Earth Reference Model), Germ Reservoir Database (available at https://earthref.org/GERMRD/6/)

Guo W., Huo S., Xi B., Zhang J. and Wu F. (2015), Heavy metal contamination in sediments from typical lakes in the five geographic regions of China: Distribution, bioavailability and risk, Ecological Enginieering, 81, 243-255.

Haines P.E. (2006), Physical and chemical behaviour and management of Intermittently Closed and Open Lakes and Lagoons (ICOLLs) in NSW (Ph.D. thesis). Griffith University, Gold Coast, 505p. 
Haines P.E., Tomlinson R.B. and Thom B.G. (2006), Morphometric assessment of intermittently open/closed coastal lagoons in New South Wales, Australia, Estuarine, Coastal and Shelf Science, 67(1), 321-332.

Heese T., Pikuła K., Wojcieszonek A., Arciszewski M. and Wawrzonkowski J. (2013), The limnological monitoring of Lake Jamno based on recording-transmiting system. In: Cieśliński R. and Jereczek-Korzeniweska K. (Eds.), Aspects of Water Investigation in XX and XXI Century, University Press, Gdańsk.

Hernández-Crespo C. and Martín M. (2015), Determination of background levels and pollution assessment for seven metals ( $\mathrm{Cd}, \mathrm{Cu}, \mathrm{Ni}, \mathrm{Pb}, \mathrm{Zn}, \mathrm{Fe}, \mathrm{Mn}$ ) in sediments of a Mediterranean coastal lagoon, Catena, 133, 206-214.

Hervé A., Factor rotations in factor analyses. http:// www.utd.edu/ herve/Abdi-rotationspretty.pdf (accessed 22 February 2018).

Honglei I., Liqing L., Chengqing Y. and Baoqing S. (2008), Fraction distribution and risk assessment of heavy metalsin sediments of Moshui Lake, Journal of Environmental Sciences, 20, 390-397.

Hounkpè J.B., Kélomè N.C., Adèchina R. and Lawani R.N. (2017), Assessment of heavy metals contamination in sediments at the lake of Ahémé in southern of Benin (West Africa), Journal of Materials and Environmental Sciences, 8(12), 4369-4377.

Huang L., Pu X., Pan J-F. and Wang B. (2013), Heavy metal pollution status in surface sediments of Swan Lake lagoon and Rongcheng Bay in the northern Yellow Sea, Chemosphere, 93, 1957-1964.

Ivanter E.V., Slukovskii Z.I., Dudakova D.S., Medvedev A.S. and Svetov S.A. (2016), Evidence for the zircon origin of cadmium anomalies in bottom sediments from the littoral zone of the northern part of Lake Ladoga, Doklady Akademii Nauk, 468(5), 562-565.

Jiang X., Wang W.W., Wang S.H., Zhang B. and Hu J.C. (2012), Initial identification of heavy metals contamination in Taihu Lake, a eutrophic lake in China, Journal of Environmental Science, 24, 1539-1548.

Kamala-Kannan S., Prabhu Dass Batvari B., Lee K.J., Kannan N., Krishnamoorthy R., Shanthi K. and Jayaprakash M. (2008). Assessment of heavy metals $(\mathrm{Cd}, \mathrm{Cr}$ and $\mathrm{Pb})$ in water, sediment and seaweed (Ulva lactuca) in the Pulicat Lake, South East India, Chemosphere, 71(7), 1233-1240.

Kim K.T., Kim E.S., Cho S.R. and Park J.K. (2009), Distribution and temporal change of heavy metals in the surface sediments of Lake Shihwa and the adjacent sea, Korea, The Journal of Coastal Research, 56, 817-821.

Lin S. and Hsieh I.J. (2002), Influence of the Yangtze River and grain size of the spatial variation of heavy metals and organic carbon in the East China Sea continental shelf sediment, Chemical Geology, 182, 377-394.

McSweeney S.L., Kennedy D.M., Rutherfurd I.D. and Stout J.C., Intermittently closed/open lakes and lagoons: Their global distribution and boundary conditions, Geomorphology, 292, 142-152.

Merchel M. (2014), The role of extreme events in the development of the coastline in the Darłówko area. In: Zielinski T., Pazdro K., Dragan-Górska A. and Weydmann A. (Eds.), Insights on Environmental Changes, Where the World is Heading, Springer.
Moore F., Forghani F. and Qishlaqi A. (2009), Assessment of heavy metal contamination in water and surface sediments of the Maharlu saline lake, SW Iran, Iranian Journal of Science and Technology, Transaction A, 33, 43-53.

Obolewski K., Jarosiewicz A. and Ożgo M. (2015), Invasive Ponto-Caspian hydrozoan Cordylophoracaspia (hydrozoa: Cnidaria) in southern Baltic coastal lakes, Estuarine, Coastal and Shelf Science, 167, 147-153.

Oumar B., Ekengele N.L. and Balla A.O.D. (2014), Évaluation du niveau de pollution par les métaux lourds des lacs Bini et Dang, Région de l'Adamaoua, Cameroun, Afrique Science, 10(2), 184-198.

Rajeshkumar S., Liu Y., Zhang X., Ravikumar B., Bai G. and Li X. (2018), Studies on seasonal pollution of heavy metals in water, sediment, fish and oyster from the Meiliang Bay of Taihu Lake in China, Chemosphere, 191, 626-638.

Saeed S.M. and Shaker I.M. (2008), Assessment of Heavy Metals Pollution in Water and Sediments and Their Effect on Oreochromis niloticus in the Northern Delta Lakes, Egypt, Proceedings of the 8th International Symposium on Tilapia in Aquaculture, Cairo, 12-14 October 2008, 475-490.

Salminen R., Batista M.J., Bidovec M., Demetriades A. De Vivo B., De Vos W., Duris M., Gilucis A., Gregorauskiene V., Halamic J., Heitzmann O., Lima A., Jordan G., Klaver G., Klein P., Lis J., Locutura J., Marsina K., Mazreku A., O'Connor P.J., Olsson S.A., Ottesen R.T., Petersell V., Plant J.A., Reeder J., Salpeteur I., Sandström H., Siewers U., Steenfelt A. and Tarvainen T. (2005), Geochemical atlas of Europe, Part 1: Background information, methodology and maps, geological survey of Finland, Espoo, 526p.

Samy Y.M. and El-Bady M.S.M. (2014), Comparative study of the mineralogy and geochemistry of the Burullus and Bardawil lake sediments, Mediterranean Sea Coast, Egypt, Life Science, 11(9), 686-700.

Shalaby B.N., Samy Y.M., Mashaly A.O. and El-Hefnawi M.A. (2017), Comparative geochemical assessment of heavy metal pollutants among the mediterranean Deltaic lakes sediments (Edku, Burullus and Manzala), Egypt, Egyptian Journal of Chemistry, 60(3), 361-378.

Siwulski M., Mleczek M., Rzymski P., Budka A., Jasińska A., Niedzielski P., Kalač P., Gąsecka M., Budzyńska S. and Mikołajczak P. (2017), Screening the multi-element content of pleurotusmushroom species using inductively coupled plasma optical emission spectrometer (ICP-OES), Food Analytical Methods, 10(2), 487-496.

Tafa B. and Assefa E. (2014), Detection of copper and zinc (heavy metals) in water of lake Chamo, Arbaminch Ethiopia, World Journal of Chemical Education, 2(3), 42-47.

Taher A.G. and Soliman A.A. (1999), Heavy metal concentrations in surficial sediments from Wadi El Natrun saline lakes, Egypt, International Journal of Salt Lake Research, 8(1), 75-92.

Tholkappian M., Ravisankar R., Chandrasekaranc A., Prince Prakash Jebakumard J., Kanagasabapathye K.V., Prasade M.V.R. and Satapathye K.K. (2018), Assessing heavy metal toxicity in sediments of Chennai Coast of Tamil Nadu using Energy Dispersive X-Ray Fluorescence Spectroscopy (EDXRF) with statistical approach, Toxicology Reports, 5, 173-182.

Thurstone L.L. (1974), Multiple Factor Analysis, University of Chicago Press, Chicago. 
Tug G.N. and Duman F. (2010), Heavy metal accumulation in soils around a salt lake in Turkey, Pakistan Journal of Botany, 42(4), 2327-2333.

Yuan H., An S., Shen J. and Liu E. (2014), The characteristic and environmental pollution records of phosphorus species in different trophic regions of Taihu Lake, China, Environmental Earth Sciences, 71(2),783-792. 